\title{
Putting Cosmogony into Words: The Neoplatonists on Metaphysics and Discourse $(\log o s)$
}

DOI: $10.14746 / \mathrm{pea} .2019 .1 .6$

ANNA MOTTA / Freie Universität Berlin /

\section{Introduction}

When Cicero speaks in favour of analogy, he argues that no writer is capable of expressing everything in a written text, and also that, if a reader comes across a text by a good writer, he or she can pass from the written to the unwritten. ${ }^{1}$ Well removed from the exegetical wave that had already engulfed literature and philosophy in the early centuries of the Empire, Cicero becomes the unwitting theoriser of an interpretative criterion that commentators were to make their own. The measure that led to the closing of the Academy in Silla's day ${ }^{2}$ also influenced the emergence of an extensive and complex exegetical

1 See Cic. Inv. rhet. 2.152. 58-64).

2 Silla closed down the Academy in 86 BC: see Glucker (1978: 242), Dörrie (1987: 546), Ferrary (2001: 
effort on the part of those philosophers who could call themselves Platonists by virtue of their close engagement with Plato's texts, ${ }^{3}$ rather than any affiliation to a philosophical institution. Although, in the new context of the imperial age, texts - I am here referring to Plato's dialogues, of course - were perceived as the key element for what was considered an ex commentario culture, they did not constitute a limiting factor. Written texts and exegesis determined a philosopher's adherence to a given current of thought, yet without stifling the creativeness of individual commentators. Regarded as a conveyor of obscuritas, ambiguities and reticence - ever since Plato's criticism of writing expressed in the Phaedrus - the written text does not prevent the exegete from passing to the unwritten, as Cicero would put it; rather, it persuades him of the need to go beyond the written word.

\section{Plato's $\lambda$ óyoı in Proclus' Commentary on the Timaeus}

The purpose of these opening remarks is not to introduce a discussion on the creative or non-literal interpretation that for centuries remained the hallmark of exegeses on the Timaeus - the dialogue that has provided the main stimuli for reflection for the present contribution. ${ }^{4}$ Nor do these introductory considerations represent a subtle attempt to newly raise the question of whether this dialogue is to be regarded as a reference to Plato's oral teaching or as a corpus of doctrines. Rather, the methodological and theoretical assumption that will guide my reflections on the Neoplatonist literary-metaphysical theory rooted in the Neoplatonist exegesis of the Timaeus is the relation between the written and the unwritten. The theory in question stresses the importance of analysing the literary representation of nature that is discussed in the dialogue by combining the investigation of physical science with that of theological science. Natural science and theology are closely related in Neoplatonism, and especially in the late Athenian Neoplatonism that constitutes the focus of the present contribution. According to the Platonic Theology, the study of physics is propaedeutic to that of theology. ${ }^{5}$ This finds an explanation and clear textual foundation in Proclus' Commentary on the Timaeus, a commentary on Plato's work that according to Iamblichus constitutes one of the pinnacles of natural scientific literature: ${ }^{6}$

${ }^{3}$ See Barnes, Griffin (1997: 112-116).

${ }^{4}$ On this text, its legacy and its fortune, see Reydams-Schils (2003).

${ }^{5}$ See Procl. Theol. Plat. I 2,10.25-11.7.

${ }^{6}$ On Iamblichus and his canon of texts, see Dalsgaard Larsen (1972: 332-423), Dillon (1973: 15). On Proclus and his Commentary on the Timaeus, see Gersh (2003: 143-153), Cleary (2006), Kutash (2011). On Proclus' indebtedness to Iamblichus as regards this commentary, see Tarrant (2007: 46-49). 


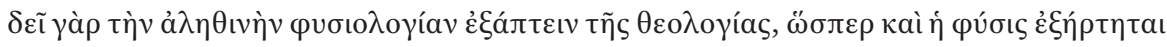

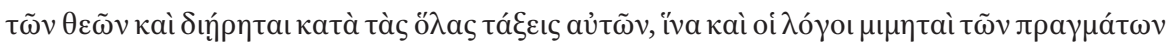

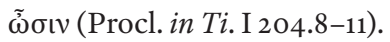

True natural science must depend on theology, just as nature depends on the gods, and is divided up according to their overall grades, in order that logoi too should be imitators of the things they are supposed to signify. ${ }^{\text {? }}$

The first interesting aspect that may be inferred from this passage is that, if nature falls among the objects of theology, it must depend upon the gods. Therefore, one cannot isolate the study of nature from the metaphysical domain - as Aristotle does in the Neoplatonists' interpretation of his Metaphysics. ${ }^{8}$ Moreover, as genuine natural science follows the arrangement of divine orders, the study of nature must concern these very same orders, which are governed by the gods: it is no coincidence that the Timaeus, which - as already noted - is ranked among the physical texts is also among the most important dialogues when it comes to Plato's mystical teaching about the gods. ${ }^{9}$ Such observations are probably the reason why the anonymous author of the Prolegomena to Plato's Philosophy (mid- $6^{\text {th }}$ cent. AD) argues that the бколó simply to teach physics but to examine the science of nature as a whole. Proclus writes that natural science encompasses the study of the All, right down to its origin, by means of images and paradigms: ${ }^{10}$ its aim is to show that the cosmos is a God, endowed with soul and intellect, which makes it a copy of the model in the Living Intellect with the participation of the Good.

Thus, the study of natural science also touches upon the "generation" of the cosmos, which is due to metaphysical causes as well as physical ones. Most importantly, it concerns the issue of the sense in which the cosmos itself is divine, even though we speak of its "generation." For although according to Proclus the cosmos is eternal, and although upholding its eternity means upholding its divinity, in a way it may be said to be "generated." The use of various forms of the verb "to generate" may be regarded as valid in this context insofar as they are used to indicate the dependence of the existence of the cosmos on other causes. ${ }^{11}$ Besides, Greek terms such as $\dot{\eta} \gamma \varepsilon ́ v \varepsilon \sigma ı \varsigma$ and tò $\gamma ı \gamma \nu o ́ \mu \varepsilon v o v$ are usually rendered as "generation," even though "becoming," "coming to be," "what comes to be" and "what is produced" would be more appropriate. Tò үıүvó $\mu \varepsilon v o v$ in all its forms

7 Translation (slightly modified) by Tarrant (2007).

8 Aristotle's Metaphysics fails to move beyond the strictly physical study of the cosmos: see Steel (2003: 175-187).

9 See Procl. Theol. Plat. I 5, 24.12.

${ }^{10}$ On the бколó of the Timaeus: Procl. in Ti. I 1.1-6; I 1.18; I 4.6-11; cf. also Lernould (2001: 32-35), Runia, Share (2008: 15-28), Lernould (2010: 149-181).

11 See Procl. in Ti. I 277.14-16. 
describes that which occurs by virtue of a cause or agent. This is clearly evident in all eighteen arguments of the De aeternitate mundi, where we read that an eternal cause eternally produces an eternal effect, which is precisely the cosmos. Moreover, if the model - which in causal terms is the paradigmatic cause - is an eternal model, the cosmos too must be

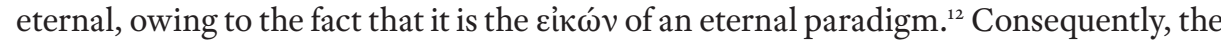
crucial point in the study of the physical world is that the eternity of the world is based on a complex set of causes.

The second question which emerges from the Proclus quote concerns $\lambda$ ó $\gamma o$, their function in the physical world, and their relation to the metaphysical one. As $\lambda$ ó $\gamma o$ a are

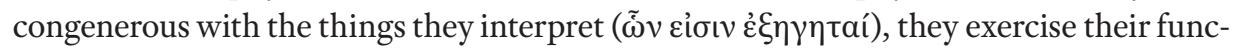
tion by virtue of the principles of similarity and analogy. However - we should add, based on what Plato argues in his invocation of the gods ${ }^{13}-$ as they are still human $\lambda$ ó $\gamma o$ that are suited to their recipients and as they are perfectly self-coherent, ${ }^{14}$ they can only be

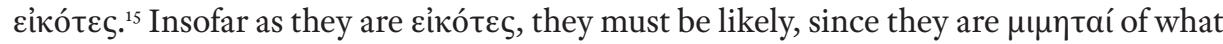
is anterior to them. It is worth emphasising that $\lambda$ ó $о$ os - a term which in addition to "speech," "word" and "doctrine" can also be translated as "reason," "reason-principle" and "ratio"16 - is an interpreter of the things that are ontologically prior. This means that in cosmo-literary theory - a theory that plays on the polysemic nature of the term $\lambda$ óyos indicates the existence of a necessary relation of resemblance (though not identity) between the written text and the metaphysical reality it analogically represents. Proclus makes a necessity of the possibility of the assimilation of $\lambda$ ó $\gamma$ ot to the things they interpret, and hence of the coexistence of physics and theology within the $\lambda$ ó $\gamma$ os as an image of the cosmos, as is shown by the use of $\delta \varepsilon \tilde{i}$ in the following text:

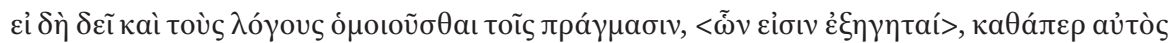

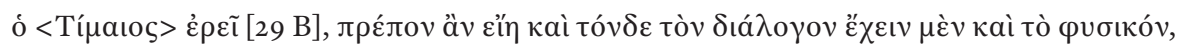

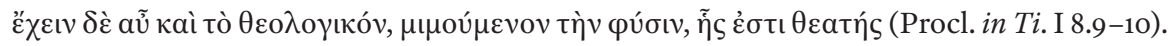

If then one should actually be making one's logoi similar to the things "of which they are interpreters" as Timaeus himself will say (29b), it would be appropriate for this dialogue also to have a theological element too as well as its physical element, in imitation of nature that is the object of its study. ${ }^{17}$

12 See Lang, Macro (2001: 1-16).

13 See Pl. Ti. 29c-d.

14 See ibidem, 29c5-6.

15 See ibidem, 29b-c.

${ }^{16} \Lambda$ ó $\gamma$ o̧ has a notoriously broad meaning in Proclus' Commentary on the Timaeus: it can refer to the ordering principles of the physical world (e.g., I 10.20), the capacity of speech (II 300.21), verbs (e.g., I 66.11), ratios (II 36.14), forms (I 143.30), and notions in the soul (I 225.22). For this reason, I have left it untranslated. On Proclus' 入óyoı see Helmig (2012: 263-333).

17 Translation (slightly modified) by Tarrant (2007). 
The Timaeus is a $\sigma \varepsilon \mu \nu$ ó dialogue, insofar as it derives its contents from above (áv $\omega \theta \varepsilon v$ ), from the highest principles, paving the way for the understanding of the world from a point of view that is not just physical but rather theological.$^{18}$ Its theological character already emerges from the rich theoretical content of these short passages. On the basis of what David T. Runia has described as "the logological principle", ${ }^{19}$ which is to say the "textual" principle of the epistemological difference between being and gener-

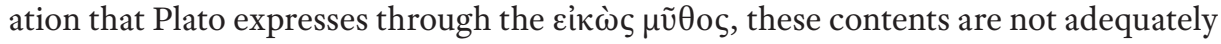
investigated in this Proclean commentary. The exegetical strategy adopted by Proclus would appear to focus more on other specific lemmas of the Timaeus. The Commentary might here be following an exegetical suggestion made by Syrianus, Proclus' master and a commentator on Aristotle's Metaphysics. Syrianus may have inferred that there was no need to embark on a detailed investigation of each and every lemma from Alexander of Aphrodisias' commentary on the Aristotelian text. ${ }^{20}$ This hypothesis would appear to find confirmation in the Vita Procli, ${ }^{21}$ where Marinus presents the Commentary on the Timaeus as one of Proclus' first works. As a youthful, albeit elegant and doctrinally rich, work, this would have been composed when the philosopher was no older than twenty-eight years, which is to say a few years after his joining the School of Athens. Consequently, this text would be a valuable re-elaboration of Syrianus' lessons. ${ }^{22}$

Proclus thus "limits himself" to commenting on this section of the Timaeus, arguing that although all Platonic $\lambda$ ó $\gamma o$ เ are similar to the things they interpret and may be assimilated to them, this is particularly true in the case of "this dialogue", i.e. the Timaeus. I will be returning to this point, which is to say the importance of the Timaeus in the cosmo-literary theory, in the last section of the present contribution. Now, before setting out to further define the relation between physics and theology, as it emerges precisely from the Timaeus, it is worth clarifying that the resemblance between a $\lambda$ ó $\gamma$ os and the reality which the $\lambda$ ó its theological content. Hence, the resemblance in question emerges, on the one hand, as a structural or morphological one and, on the other, as a content-related or semantic one. In order to understand the structure or morphology distinguishing the resemblance between macrocosm and microcosm, we must consider the powerful image of the "generation" of the world of $\lambda$ ó $\gamma$ o to be found not in the Commentary on the Timaeus but rather in the anonymous Prolegomena to Plato's philosophy. Based on the lectures delivered by an anonymous Alexandrian teacher of the $6^{\text {th }}$ century $\mathrm{AD}$, this text would appear to be deeply indebted to the mature Proclus and his way of introducing the study of Plato and his dialogues, i.e. to Proclus the diadochos rather than the young Proclus who attend-

\footnotetext{
18 See Procl. in Ti. I 8.2-5.

19 See Runia (1997: 111).

20 See Syr. in Met. 54.12-21.

21 Marin. Procl. 13.10-19.

22 See Martijn (2006: 151-167).
} 
ed Plutarch's lectures and was a disciple of Syrianus'. For the first time in the history of philosophy, in the Prolegomena Plato is explicitly associated with the Demiurge: ${ }^{23}$

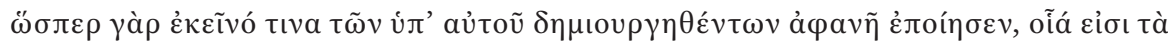

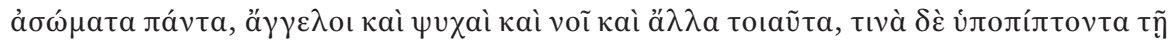

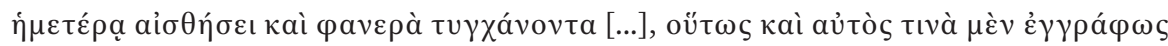

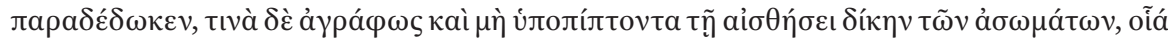

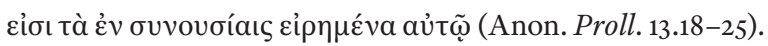

For just as God has made some parts of his creation invisible, namely all incorporeal beings, angels, souls, intelligences, etc., others, however, subject to our perception and visible [...], so Plato too has handed on some of his ideas in writing and some by word of mouth, like incorporeal entities, imperceptible to the senses, namely what he said in his lectures ${ }^{24}$.

\section{The morphology of $\lambda$ óyoı}

The studies by Coulter, Brisson and Radke-Uhlmann have shown that the Prolegomena may be legitimately described as the text that enshrined the late-antique cosmo-literary theory by virtue of the fact that it picked up and further developed some of Iamblichus and Proclus' considerations ${ }^{25}$. These considerations allow us to interpret the structure of the dialogue as an analogical reflection of that of the universe. Moreover, using the Demiurge - the divine craftsman of the cosmos - as a term of comparison for the craftsman of dialogical literature entails reassessing the role of the written text and assigning the language of the dialogues - images of those oral lectures which Aristotle refers to in widely discussed passages ${ }^{26}$ - the same character of likeliness that distinguishes

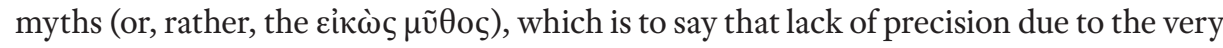
nature of human language, and particularly written language, which nonetheless does not completely invalidate the message.

In the Prolegomena this theorisation is expressed through the simile introduced by

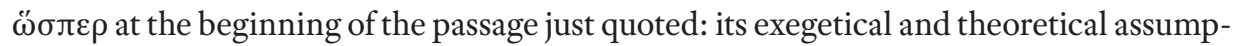

${ }^{23}$ On the centrality of the Demiurge and demiurgy in Plato's Timaeus and Proclus' Commentary, see Neschke-Hentschke (2000: ix-xxvii), Lernould (2001: 103-112).

24 Translation by Westerink (1962).

25 See Coulter (1976), Brisson (1987: 121-128), Radke-Uhlmann (2006).

${ }^{26}$ Arist. Ph. 209b14-15 e Metaph.987b18-22. In the Prolegomena, we read that although Plato had initially chosen to focus exclusively on oral teaching (following the illustrious examples of Socrates and Pythagoras), he then decided to leave behind him (apart from his disciples) also some dialogues, as the best possible record of his oral teachings. The exceptional result is due to the assimilation of the dialogues to the cosmos, and vice-versa. As the $\mu$ í $\eta_{\gamma} \iota \varsigma$ of divine creation, the Platonic creation overcomes the alleged inadequacy of written books. 
tion may be found in the Timaeus and in Proclus' commentary on this dialogue. Plato's work may be compared to that of the Demiurge in the Timaeus, but also to that of Timaeus himself, who is the craftsman of a discourse, insofar as he gives life and verbal expression to it: ${ }^{27}$ using a verbal image, Timaeus "generates" a discourse, a discourse that is a cosmos revolving around another cosmos, that cosmos which includes the divine Demiurge among its key figures. But let us proceed in order, starting from Plato's text. The last page of the Timaeus, which seems to sum up the various aspects of the discourse about cosmogony, lends confirmation to the theoretical topos that leads to the development of the simile presented in the Prolegomena:

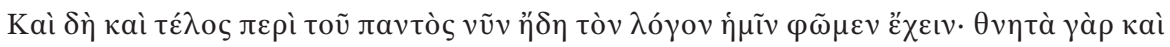

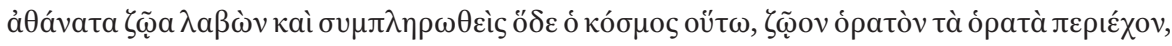

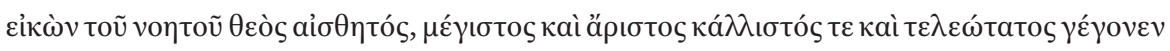

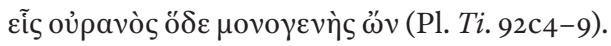

Here at last let us say that our discourse concerning the universe comes to its end. For having received in full its complement of living creatures, mortal and immortal, this world has thus become a visible living creature embracing all that are visible and an image of the intelligible, a perceptible god, supreme in greatness and excellence, in beauty and perfection, this Heaven single in its kind and one.28

While there can be no doubt that the formulation of the Neoplatonist simile and the corollaries deriving from it spring from an insight provided by the Timaeus, it is also clear that the anonymous author of the Prolegomena was not the first Neoplatonist author to establish a relation between Plato's activity and that of the Demiurge. Already in Proclus' texts - to limit our time frame to the schools of Athens and Alexandria in the $5^{\text {th }}$ and $6^{\text {th }}$ century AD - Plato expresses himself as though he were uttering his words together with the Demiurge. ${ }^{29}$ In the Commentary on the Cratylus, Plato is the one who knows the original model and the demiurgic art. ${ }^{30}$ Endowed with the uttermost representational skill, ${ }^{31}$ he is the greatest of all craftsmen of $\lambda$ ó ${ }^{\circ}$, since the knowledge of the model enables him to clearly represent things in words. ${ }^{32}$

The innovative aspect which distinguishes the anonymous Alexandrian text from the surviving Athenian ones from the same period is, therefore, the explicitformulation of the relation between the creation of the dialogues and demiurgic production. The

\footnotetext{
27 See Pl. Ti. 27a7-8.

28 Translation by Cornford (1956).

29 See Procl. in Ti. I 423.25-26.

30 See Procl. in Cra. XX 8.

31 See ibidem, XIV 5.16.

32 See Pl. Ti. 19e1-2.
} 
anonymous author explains this relation in terms of Plato's friendship with the deity, a friendship that - as is often the case - leads one friend to follow the other's example. ${ }^{33}$ The anonymous text extensively deals precisely with this notion of wishing to follow the example of God and his accomplishment of the divine work. ${ }^{34}$ Divine friendship and

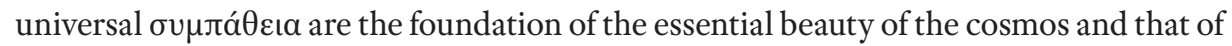
the dialogues. Echoing Anaxagoras through Numenius' fragment 41, the Neoplatonists claim that "all things divine are in all things, and they are unified by one another, so that all are in one and each is in all and they are held together by divine friendship." ${ }^{35}$

Another certainly innovative aspect that may be ascribed to the Prolegomena is the assimilation of $\lambda$ ó $\gamma$ os to the cosmos, an assimilation that marks a significant shift from an exclusively biological interpretative perspective - connected to the Phaedrus - to a teleological perspective, conditioned by the importance of the Timaeus. In the Prolegomena we read:

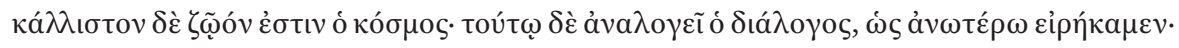

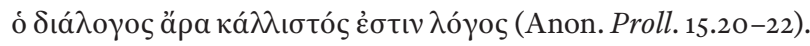

The most beautiful living being is the world, and the dialogue can be compared with the world, as we have already said; consequently the dialogue is the most perfect $\log 0$ s. $^{36}$

Explicating one of the features of the $\pi \alpha v \tau \varepsilon \lambda \varepsilon^{\prime} \zeta \tilde{\omega}$ ov - which is to say beauty - the anonymous author affirms that $\lambda$ ó ${ }^{\circ}$ s is analogous not to just a living being, i.e., any of those living beings that exist in the form of parts, ${ }^{37}$ but to the most beautiful of all living beings..$^{38}$ Its beauty is determined by the fact that, like the macrocosm, it "is generated" by a Demiurge who follows a model that is the best intelligible model, ${ }^{39}$ even though this model - as Proclus specifies - is not the only one..$^{40}$ Hence, as an analogical image the $\lambda$ óyos possesses everything that the total and perfect living being possesses and contains as a model. This means that its beauty - since, as Proclus says, the sensible cosmos is the

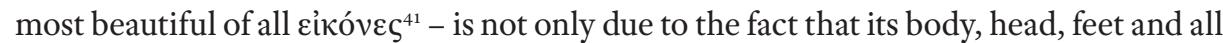

33 See Anon. Proll. 13, 27-29. For a discussion of the implications of this claim, see below. The topic of friendship in Neoplatonism is the focus of the highly interesting work of Tzamalikos (2016).

34 See Anon. Proll. 13.16; 7-8.

35 Procl. in Ti. I 17.30-18.3.

36 Translation (slightly modified) by Westerink (1962).

37 See Pl. Ti. 30c4-7.

38 See ibidem. 92c9.

39 See Procl. in Ti. I 335.6.

40 See ibidem, I 418.6-16; 421.7-12; 431.28-433.11.

${ }^{41}$ See ibidem, I 335.12-20. 
other parts are coordinated, both with one another and with the whole, ${ }^{42}$ but - as the Timaeus suggests in relation to the cosmos - the Platonic $\lambda$ ó $\gamma$ os is beautiful by necessity. ${ }^{43}$ Rather - as we read in Aristotle's De partibus animalium - the functional arrangement of all parts in view of an aim makes organisms beautiful because this aim lies in the realm of beauty. ${ }^{44}$

The aim of demiurgic creation is clearly the Good: "He was good [...] he desired that all things should come as near as possible to being like himself (Pl. Ti. 29e1-3)." When conceived in such terms, the relation between creator and artefact must be assigned final causality: for the One/Good is the final cause of the cosmos of sensible living beings ${ }^{45}$

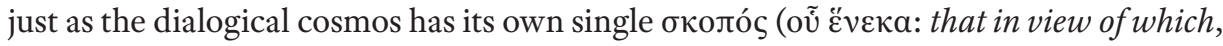
i.e. the aim itself ${ }^{46}$ ), which accounts for both its unity and life. ${ }^{47}$ With regard to the One/ Good, I do not wish to jump to the conclusion that the Demiurge of the Timaeus, the Good of the Republic and the One of the first hypothesis of the Parmenides are exactly the same thing for the anonymous author. At one point, he appears to be attributing both final causality and efficient causality to the Demiurge with respect to the physical world, based on the above-mentioned passage from the Timaeus, although he continues to regard the First Principle, i.e., the One, as the comprehensive and final cause of all beings. ${ }^{48}$

In addition to beauty, another distinguishing feature of the perfect living being is precisely life. With regard to this aspect of the cosmos, Plato expresses himself in the Timaeus as follows:

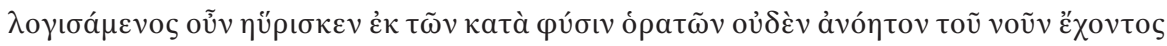

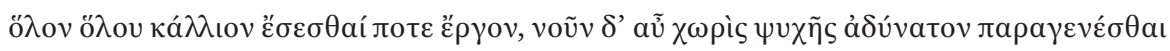
$\tau \omega(\mathrm{Pl}$. Ti. 3ob1-3).

Taking thought, therefore, he found that, among things that are by nature visible, no work that is without intelligence will ever be better than one that has intelligence, when each is taken as a whole, and moreover that intelligence cannot be present in anything apart from soul. ${ }^{49}$

In order to maintain the analogy between the macrocosm and the microcosm, and to preserve the view expressed in the Phaedrus about the negative aspects that characterize

\footnotetext{
${ }^{42} \mathrm{Pl}$. Phdr. 264c. On the image of the $\lambda$ ó $\gamma$ os as a body, see Brisson (1982: 71-75) and (1987: 121-128).

43 See Pl. Ti. 28a.

44 See Arist. $P A$ 645a8-27.

45 See Procl. in Ti. I 335.11-12 and Anon. Proll. 17.42-48.

46 See Anon. Proll. 23.9-10.

47 See Arist. Po. 1459a17-20.

48 See Procl. Inst. 92.

49 Translation by Cornford (1956).
} 


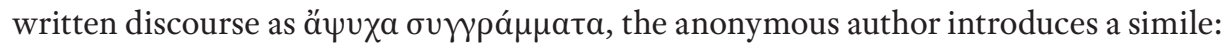
similarly to the Demiurge Zeus - the very Zeus whom Olympiodorus, following Proclus, discusses through the lens of the Cratylus - Plato is the one through whom there is life ${ }^{50}$ ( $\delta$ ' o v tò $\zeta \tilde{\eta} v$ ). This applies both to the microcosmic and macrocosmic level, where he is the causal principle of life. However, he is also the one through whom life belongs to all living beings - the Demiurge is the efficient cause: the best of all causes of the cosmos ${ }^{51}$

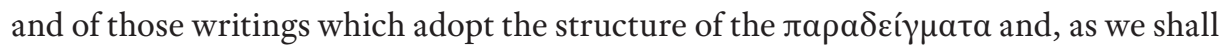
see in relation to the Timaeus, even reproduce their content. The Demiurge, therefore,

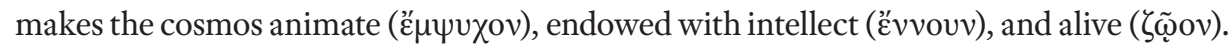

Let us now turn to the macrocosmic and microcosmic causal system. If we follow Aristotle's suggestion, we must admit that in order to understand something it is important first to examine its causes, ${ }^{52}$ and also that, speaking in general and by analogy, all things have the same causes and - to use an Anaxagorean expression - the same first principles. ${ }^{53}$ Thus, just as in order to understand $\varphi v \sigma ı \lambda$ oүía we must examine the causes of the universe and reach the conclusion that the physical world is the outcome of a demiurgic act, so we are bound to reach the same conclusion if we reflect on the dialogical cosmos and its causes, which by analogy are the same as those of the macrocosm. The Neoplatonist causal system identifies five causes, of which only three may be regarded as genuine ones, since the others only have the role of accessory causes: Proclus discusses this at the beginning of his Commentary on the Timaeus as well as in other sections of the same work. Particularly, in one passage of the Commentary, Proclus adopts a "präpositionale Umschreibung" probably of the school origin ${ }^{54}$ to present the system of six rather than five causes, which is the one the anonymous author refers to when constructing his microcosm:

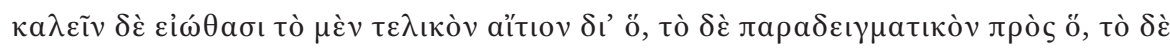

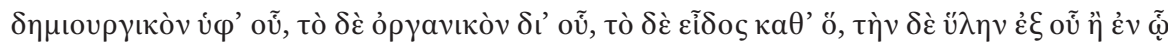
(Procl. in Ti. I 357.13-15).

${ }^{50}$ See Olymp. in Phd. 1 \$ 20.5-6; Procl. in Cra. CI 52.4-8; Procl. Theol. Plat. V 22, 79. 21-80.8.

${ }^{51}$ See Procl. in Ti. I 335.12-20. Scrive Cleary (2006: 143-144): "In another of his revealing digressions, Proclus (in Tim. I.260.19-261.1) discusses the metaphysical implications of Plato's concept of aition. By means of term "cause" (aition), Plato reveals the unique character (henoeidê) of the demiurgic principle, in the sense that the name "cause" indicates that which produces (to demiourgikon) and not simply that which sustains (to hupostatikon) another thing. Notice that in insisting upon the singularity of the efficient cause here (cf. also 262.2), presumably so as to distinguish it from the formal and the final cause, Proclus seems to imply that the term "cause" belongs most properly to efficient causality."

52 See Arist. APo. 71b9-11; APo. 94a20; Ph. 194b17-20.

53 See Arist. Metaph. 1070a 31-35.

54 On this formulation see Dörrie (1969: 217-228) and Dörrie, Baltes (1996: 128-146, 408-439). 
[Philosophers] normally call the final cause the "on account of which," the paradigmatic the "after which," the demiurgic the "by which," the instrumental the "by means of which," the form the "in accordance with which," the matter the "out of which" or "in which." ${ }_{55}$

Compared to Proclus' six-cause macrocosmic system, the microcosmic one is presented in the Prolegomena both by analogy with the principles of reality and through the propositional argument. ${ }^{56}$ The two presentations are not antithetical or divergent; rather, they appear to be connected, since the principles are also causes. The literary theory, which Proclus refers to in his Commentary on the Alcibiades, does not clarify its own relation to the causes of the universe, but rather draws an analogy between the microcosm and the parts of the All - parts which Proclus identifies as the Good, the Intellect, the Soul, form, and nature as substratum. ${ }^{77}$ However, this theory still underlies that of the five causal principles. The Commentary on the Alcibiades only illustrates the

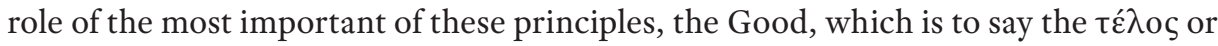
бколо́ $\varsigma^{58}$ that holds together the discussion in the dialogue for the sake of a single aim. In the Commentary on the Alcibiades, just as in the Commentary on the Timaeus, Proclus devotes few passages to explaining the general structure of the cosmo-literary theory. The reason, in this case, is explicitly stated: it is not that the discussion about such a structure is unimportant or of little metaphysical significance; rather, it has been presented

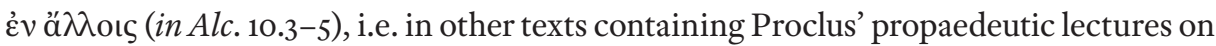
Platonic philosophy. ${ }^{59}$ The general principles governing Neoplatonic exegesis are therefore expounded in introductory texts and preliminary lectures that are fundamental for aspiring philosophers: the lack of discussions on the subject in the commentaries should not lead us to underestimate the importance of such matters for the Neoplatonists, particularly in light of the close relation that was established between exegesis, theory and teaching in Late Antiquity.

When examined in relation to the other commentaries, and its systematic characteristics and those of the literary genre to which it belongs, the text of the Prolegomena proves to be a crucial source illustrating the importance of the relation between the macrocosm and the microcosm, between the exegesis of the universe and the exegesis of the text:

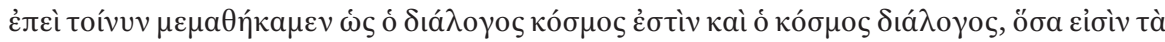

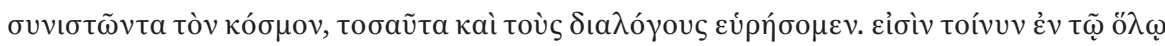

55 Translation by Runia, Share (2008). On the “präpositionale Umschreibung”, see Trouillard (1982), Dörrie (1974: 121-138), Donini (2010: 341-357).

56 See Motta (2018: 204-212).

57 See Procl. in Alc. 10.1-19.

58 See Procl. in Alc. 10.2-3 and 17-19.

59 On the various hypotheses surrounding these lost Proclean texts, see Plezia (1949: 86), Westerink (1962: xli) = Westerink, Trouillard, Segonds (1990: lxxv), Hadot (1990: 31), Mansfeld (1994: 22-23). 


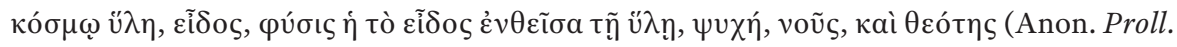
$16.3-7)$.

As we have seen, then, that the dialogue is a cosmos and the cosmos a dialogue, we may expect to find all the components of the universe in the dialogue. The constituents of the universe are these: matter, form, nature (which unites form with matter), soul, intelligence, and divinity. ${ }^{60}$

$\Lambda$ óyoc is governed by the same principles that govern cosmology, and through them it reproduces its causality, allowing us to draw the same implications from it. Proclus explicitly states that the cosmos is a single living being made up of a multiplicity of other living beings that live by virtue of demiurgic causality. ${ }^{61}$ It is on the basis of this notion that the anonymous author develops his idea of the overall unity of the microcosm, even though the macrocosm of which it is an image comprises a multiplicity of unitary living

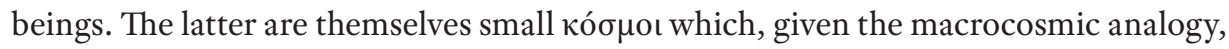
i.e., the fact that they are composed of the very elements constituting the cosmos, reproduce the macrocosmic causal system:

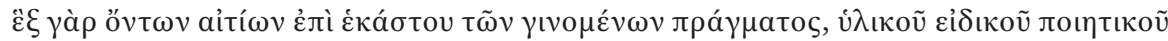

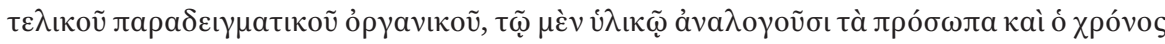

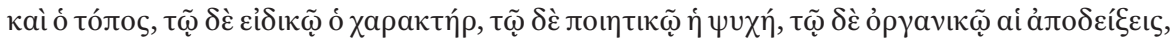

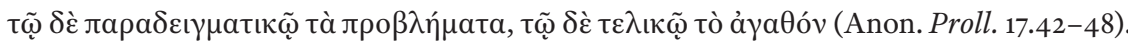

Since there are six kinds of causes acting on everything in creation, the material, the formal, the efficient, the final, the exemplary and the instrumental cause, the analogues of the material cause are the characters and the time and the place, of the formal cause the style, of the efficient cause the soul, of the instrumental cause the arguments, of the exemplary cause the problems, of the final cause the good of the dialogue. ${ }^{62}$

\section{The semantics of $\lambda$ ó yot}

The analogy between the macrocosm and the literary microcosm is used to demonstrate the resemblance, though not identity, between the secondary and the primary realities. It is the Commentary on the Timaeus that most explicitly discusses the role played by analogy, the device allowing us to pass from one world to the other:

\footnotetext{
60 Translation by Westerink (1962).

61 See Procl. Theol. Plat. V 22, 80.26-81.2.

${ }^{62}$ Translation by Westerink (1962).
} 


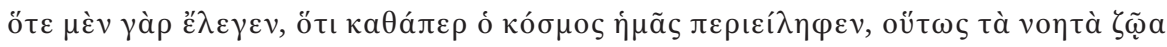

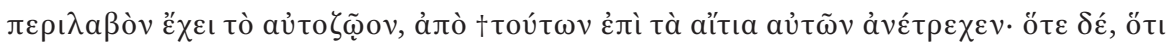

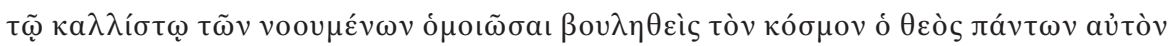

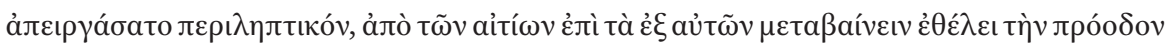

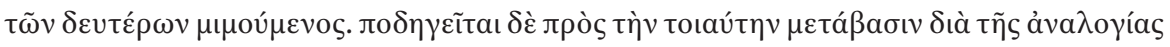
(Procl. in Ti. I 433.16-23).

For when we said (3oc7-a1) that "just as the cosmos has embraced us, so does the Living-Thingitself hold the intelligible living things in its embrace", he was ascending from things here below to their causes, and when [he said] (3od1-31a1) that since the god wished to make the cosmos like the most beautiful of intelligible beings, he made it inclusive of all things, his purpose was to pass from the cause to the things which arise from them in imitation of the procession of the secondary [realities]. He was led to such a transition by the analogy. ${ }^{63}$

Ava $\lambda$ oyía, ${ }^{64}$ therefore, is a way to represent something that lies at a higher level by means of something else located at a lower level. At the same time, it is a way to ascend from the image to the model, from the effect to the cause, through a causal dynamism that $\lambda$ ó $\gamma$ o too are capable of revealing. This aspect is made explicit by the use of the adverb ává, which does not so much refer to a division (in the distributive sense) as rather emphasises a reproduction (in the iterative sense), ${ }^{65}$ a reproduction that enables a particular sort of recollection which does not fully coincide with the Platonic one. This recollection does not allow us to immediately ascend from sensible knowledge to knowledge of the ideas, but only to pass from one aspect of reality, which constitutes a directly visible image, to a property of the higher reality that is not directly visible. Speaking in this

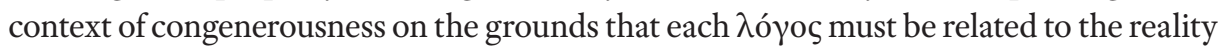
it interprets, is not tantamount to postulating the existence of a resemblance, superficial affinity or causal link between the idea and the sensible object; rather, it entails revealing and acknowledging a relation of functional identity between realities belonging to different planes of being, i.e., a kind of "functional identity" that may be discovered by examining $\lambda$ ó ${ }^{\circ}$ o, which Proclus explicitly defines as "knowledge unfolded."

In his Platonic Theology, Proclus emphasises the importance of the theme of resemblance and of a universal connection ${ }^{67}$ to indicate the essential perspective which one must adopt in the study of reality, since sensible realities are images of intelligible realities,

63 Translation by Runia, Share (2008).

${ }^{64}$ In the Elements of Theology, the term is a recurrent one: it is often used, for instance, to indicate the condition of the hypostases and of other entities in relation to the One. By analogy with the One, the unparticipable monads resemble and approximate it. See Procl. Inst. 100.90 and 108.96.

${ }^{65}$ See LSJ s.v. ảvá and Chantraine (1999) s.v. ảvá.

${ }^{66}$ See Procl. in Ti. I 342.16.

${ }^{67}$ Procl. Theol. Plat. VI 4, 22.25-24. 20. 
according to the principle of analogy. In order to study sensible reality, one must adopt the perspective of the intelligible, ${ }^{68}$ just as in the study of physics one cannot limit the enquiry to physical causes but must also consider metaphysical ones. This is the reason why the Timaeus and the Parmenides are both placed at the summit of the two-cycle curriculum in Neoplatonist schools: on the one hand, the Parmenides does not completely leave aside those beings which are in the All; on the other, the Timaeus does not entirely overlook intelligible things, since what is sensible paradigmatically exists in the intelligible and what is intelligible iconically exists in the sensible. ${ }^{69}$ The discussion on the causal system, the demiurgic intellect and the Good in the Timaeus allows us to further investigate the intelligible and to define the whole sensible cosmos as a god endowed with intellect and soul. It is through observations of this sort that the theological exposition reconciles itself with the physical бколо́

In the Neoplatonist universe, which is marked by analogical relations across various levels and by virtue of which the intelligible is iconically present in the sensible, the

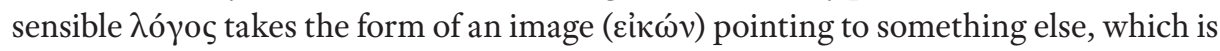
not merely the unwritten - the oral lecture. $\Lambda$ ó the realities which they interpret; ${ }^{70}$ they are the effect of a cause to which one can ascend, the reflection of a higher reality. Consequently, they can serve as a means of conversion

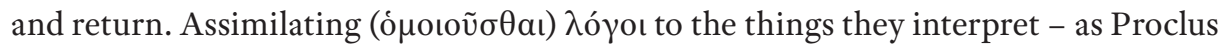
feels compelled to do - means positing the existence of a metaphysical movement of procession and return that must be centred on them; it means that these $\lambda$ ó $\gamma o$ o behave by analogy with the essential $\lambda$ ó $\gamma o$ of our soul. Indeed, the substance of the soul is $\lambda$ ó $\gamma \circ$ and the soul depends on the Demiurge, which moulds it according to perfect measures

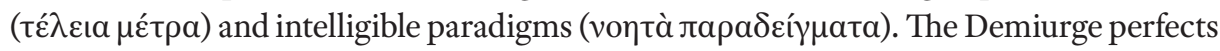
the substance of the soul by generating multiplicity within it, creating an order through harmony and keeping its divisions together. ${ }^{71}$ Thus, according to the will of the Demiurge,

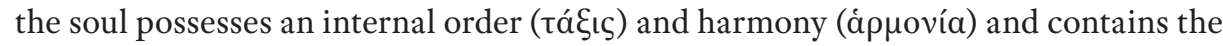
principles of both its harmonious procession and its return.

On the basis of these considerations, we may now focus our attention not on the microcosm of the dialogue as an image of the macrocosm, but rather on the cosmos of the Timaeus, i.e., that of an individual dialogue, rereading it according to the literary-metaphysical suggestions provided in the Prolegomena so as to discuss the content of the $\lambda$ ó $о$ o and the semantic analogy, so to speak, between the two кó $\sigma \mu$ o.

Having acknowledged the existence of matter, form, nature, soul, intellect and divinity in Plato's text, ${ }^{72}$ and having established that the constituents of the physical and meta-

\footnotetext{
${ }^{68}$ This might explain the passage ibidem, I 6, 29.24-30.3.

69 See Procl. in Ti. I 12.30-13.10.

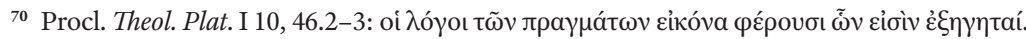

71 See Procl. in Ti. II 194.4-17.

${ }^{72}$ See Anon. Proll. 16.1-6 as well as Procl. in R. I 5.19-25.
} 
physical cosmos can also be studied on a causal basis, ${ }^{73}$ we can show not only the classic unity of form and content, but also the vital beauty of a literary form that proves suited

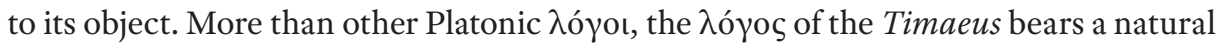
resemblance to its object, because it is not just its morphology that points to the paradigm, but its semantics too. Indeed, the content of the Timaeus concerns the universe and its causal generation. Hence, it is the parallels in both structure and content between reality and the discourse of the Timaeus that reveal the strongly anagogic nature of the dialogue, almost as though Plato had chosen to highlight the degree of its resemblance to its object, so that the text - like the $\lambda$ ó $\gamma$ os of the soul - could reveal its role as a means of conversion. For Proclus, the cosmogony expounded in the Timaeus is, first of all, a $\lambda$ ó $\gamma \circ$ $\delta ı \delta a \sigma \kappa a \lambda \iota \kappa o ́ \varsigma,{ }^{74}$ i.e., a literary cosmos that, by intertwining sequences of scenes similar to those unfolding in the cosmos, beginning with its generation, teaches the contents of its object in the only reasonably possible way:

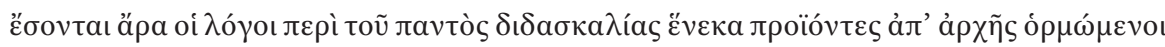

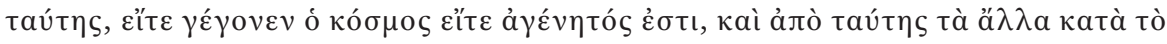

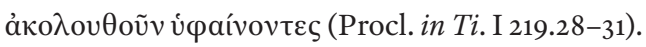

The logoi concerning the universe, therefore, will be advanced for the sake of instruction and have as their point of departure the question whether the cosmos has come into being or is ungenerated, braiding the remainder in sequence from this [beginning].75

The teaching imparted by this cosmos may be inferred from the analogy not only with metaphysical causality but also with physical causality. The anonymous author of the Prolegomena states that on a microcosmic level matter corresponds first of all to the characters. ${ }^{7}$ In the section of the Commentary on the Timaeus that Proclus devotes to the characters, Timaeus is indeed analogous to the Demiurge, while the other three speakers are analogous to the demiurgic triad (the demiurgic intellect, the soul, and universal nature): Socrates (the summit of the triad), Critias and Hermocrates receive Timaeus' words as the demiurgic triad receive the $\lambda$ ó $\gamma$ o from the Demiurge. ${ }^{77}$ It is evident that, just as the Demiurge is the highest intermediary between the intelligible and the sensible, so Timaeus acts as an intermediary for his listeners through his $\lambda$ ó $\gamma$ os. The form of the dialogue confirms the relation between physics and theology because its style analogically corresponds to the macrocosmic form: the style of the Timaeus is the lofty one that distinguishes the theological dialogues. What constitutes an altogether more

\footnotetext{
73 See Anon. Proll. 16-17.

${ }^{74}$ See Procl. in Ti. I 338.5.

75 Translation (slightly modified) by Runia, Share (2008).

${ }^{76}$ See Anon. Proll. 16.8-12; Alb. Introductio in Platonem, I 147.18-21; D.L. 3.48.

77 See Procl. in Ti. I 9.15-24.
} 
complex matter is nature, which is listed among the accessory causes of the microcosm and bestows form upon the matter of the dialogue. In Proclus' system - the anonymous author's model ${ }^{78}$ - nature is regarded as a demiurgic cause, the last of the demiurgic causes of the material and sensible world - as Proclus states - that lies at the limit of the level of

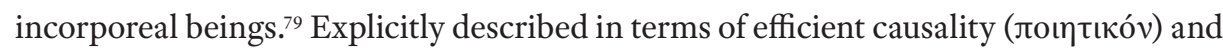

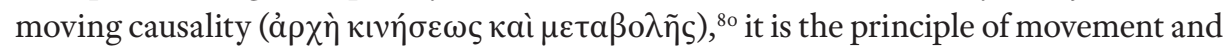
existence. These expressions, which are typically used to describe the "generation" of the physical world, would be enough in themselves to justify the hypothesis of the demiurgic function of nature. Cosmic nature and the nature of the discourse both appear to be immanent devices capable of lending matter a shape akin to the immaterial and intelligible reality, which it only reflects as an image. Nature is capable of representing the undivided through the divided, the eternal through that which changes over time, the intelligible through the sensible. ${ }^{81}$ Proclus writes:

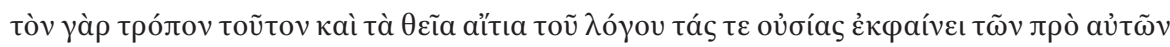

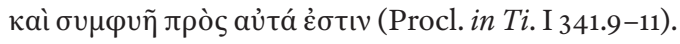

In the same way the divine causes of the account reveal both the essences of the realities prior to them and are linked to them by nature. ${ }^{82}$

At the microcosmic level, nature represents the way in which the conversation takes place. In the Timaeus the conversation consists in an exposition of discourses on cosmogony, an exposition that in its initial section takes the form of a hymn to the Demiurge. ${ }^{8}$ The invocation of the gods at the beginning of the dialogue shows that Timaeus is following

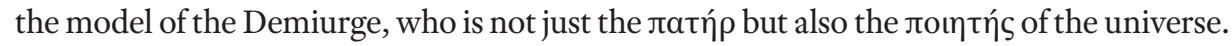
Indeed, before accomplishing his creative work, the Demiurge visits the Oracle of the Night in order to be filled with divine thoughts and receive the creative $\lambda$ ó $\gamma o$ enabling him to imbue everything with the divine and make the level of reality that is perceivable

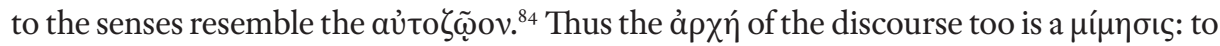
be more precise, it is a $\mu$ í sion of those beings that, prior to the "generative" stage, remain with the gods ( $\mu \varepsilon$ vovta

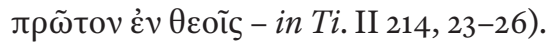

78 See Motta (2014: 26-34).

79 See Martijn (2010: 39-40).

80 See Procl. in Ti. I 261.26 and III 119.24.

${ }^{81}$ See Procl. in R. I 77.13-16 and in Ti. I 341.6-11.

${ }^{82}$ Translation by Runia, Share (2008).

${ }^{83}$ See Pl. Ti. 27c6-d1. For a discussion on the invocation of the gods in the Platonic Theology, see Motte (2000: 91-108).

${ }^{84}$ See Procl. in Ti. I 206.26-207.20. 


\section{Conclusions}

Putting cosmogony into words means creating a discourse, and creating a discourse is like creating the cosmos: it is always a matter of $\lambda$ ó cosmos, the Demiurge Plato, and Timaeus make their own inner $\lambda$ ó $\gamma$ o visible, albeit in different ways: in the Platonic Theology we read that discourse engenders "images put into motion by inner visions." This is comparable to the activity of the Demiurge, who

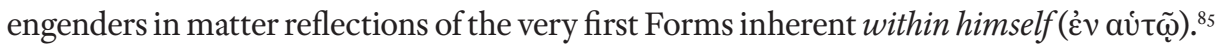
Indeed, Timaeus himself is the creator of a discourse, since he lends sensible shape to his knowledge and asks to express his thought (Pl. Ti. 27d3-4: "so that [...] I may give the clearest expression to my thought on the theme proposed"). Proclus apparently sets out from this request of Timaeus' in order to examine the analogy to be found between the father of the cosmos and the father of the $\lambda$ ó $\gamma$ os:

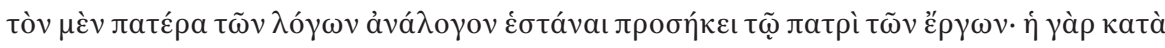

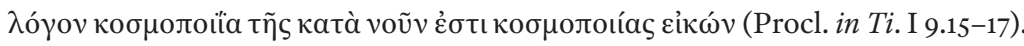

I shall reply that it's because the father of the words should have a position analogous to the father of the logoi, because this cosmic creation according to logos is an image of the cosmic creation according to intellect. ${ }^{86}$

Thus, the Timaeus emerges in Neoplatonism as a кобнолоїа on multiple levels:

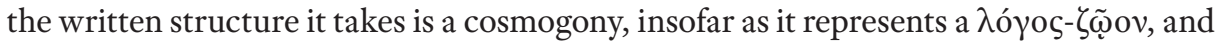
so is the verbal form in which Timaeus informs his listeners about the cosmogony of the macrocosm. It is possible to argue, therefore, that in the Timaeus Plato highlights the anagogic effect of discourse, since in this dialogue - which teaches by means of images ${ }^{87}$ and must be read in the light of its iconic structure ${ }^{88}$ - the widespread use of the exegetical device par excellence, i.e., analogy, defines the modes of assimilation to the divine across not just different levels but different kó $\mu_{\mu o t}$ If, then, according to what has been argued so far, by metaphysics we also mean the possibility of establishing a resemblance between the various levels of reality - a resemblance based on analogy - then the Platonic $\lambda$ ó $o$ o, as anagogic elements, have a place not just in Neoplatonist literary theory but also in Neoplatonist metaphysics.

\footnotetext{
${ }^{85}$ Procl. Theol. Plat. I 29, 124.26-27. On Proclus' Demiurge and the relation between the Demiurge of the Timaeus and the role played by the Demiurge in the Platonic Theology, see Dillon (2000: 339-349).

86 Translation (slightly modified) by Tarrant (2007).

87 See Procl. Theol. Plat. I 4, 19.6-12.

88 See Procl. in Ti. I 1.25-26.
} 


\section{Bibliography}

BARnes, J., Griffin, M. (eds.), 1997, Philosophia Togata II. Plato and Aristotle at Rome, Oxford.

BRIsson, L., 1982, Platon. Les mots et les mythes, Paris.

BRISSON, L., 1987, Le discours comme univers et l'univers comme discours, in: M. Costantini, J. Lallot, A. Le Boulluec (éd.), Le texte et ses représentations, Paris, pp. 121-128.

Brittain, C., 2001, Philo of Larissa. The Last of the Academic Sceptic, Oxford.

Chantraine, P., 1999, Dictionnaire étymologique de la langue grecque. Histoire des mots, Paris.

Cleary, J. J., 2006, Proclus as a Reader of Plato's Timaeus, in: H. Tarrant, D. Baltzly (eds.), Reading Plato in Antiquity, London.

CoRnford, F. M., 1956, Plato’s Cosmology, London.

Coulter, J. A., 1976, The Literary Microcosm. Theories of Interpretation of the Later Neoplatonists, Leiden.

DALSGAARD LARSEN, B., 1972, Jamblique de Chalcis, exégète et philosophe, Aarhus.

Dillon, J., 1973, Iamblichi Chalcidensis in Platonis Dialogos Commentaria, Leiden.

Dillon, J., 2000, The Role of the Demiurge in the Platonic Theology, in: A. A.-Ph. Segonds, C. Steel (eds.), Proclus et la Théologie platonicienne, Leuven-Paris, pp. 339-349.

Donini, P., 2010, I fondamenti della fisica e la teoria delle cause in Plutarco, in: M. Bonazzi (ed.), Commentary and Tradition. Aristotelianism, Platonism, and Post-Hellenistic Philosophy, Berlin-New York, pp. 341-357.

Dörrie, H. (hrsg.), 1987, Der Platonismus in der Antike. Bd. 1: Die geschichtlichen Wurzeln des Platonismus, Stuttgart-Bad Cannstatt.

Dörrie, H., 1969, "Praepositionen und Metaphysik“, Museum Helveticum 26, pp. 217-228.

Dörrie, H., 1974, “Zur Methodik antiker Exegese“, Zeitschrift für die Neutestamentliche Wissenschaft 65, pp. 121-138.

Dörrie, H., Baltes, M. (hrsg.), 1996, Der Platonismus in der Antike. Bd. 4: Die philosophische Lehre des Platonismus. Einige grundlegende Axiome / Platonische Physik (im antiken Verständnis) I, Stuttgart-Bad Cannstatt.

FERrary, J.-H., 1988, Philhellénisme et impérialisme, Rome.

Gersh, S., 2003, Proclus' Commentary on the Timaeus - Prefatory Material, in: R. W. Sharples, A. Sheppard (eds.), Ancient Approaches to Plato's Timaeus, London, pp. 143-153.

GLuCKer, J., 1978, Antiochus and the Late Academy, Göttingen.

Hadot, I. (ed.), 1990, Simplicius, Commentaire sur les Catégories d'Aristote, vol. 1, Leiden-New York.

Helmig, CH., 2012, Forms and concepts: concept formation in the Platonic tradition, Berlin.

Kutash, E., 2011, The Ten Gifts of the Demiurge. Proclus' Commentary on Plato's Timaeus, London-New York.

LANG, H. S., Macro, A. D. (eds.), 2001, On the Eternity of the World. De aeternitate Mundi. Proclus, BerkeleyLos Angeles-London.

Lernould, A., 2001, Physique et théologie: lecture du Timée de Platon par Proclus, Villeneuve d'Ascq.

LERnould, A., 2010, Le «but » et le « caractère » du Timée dans l'In Timaeum de Proclus. La fonction herméneu-

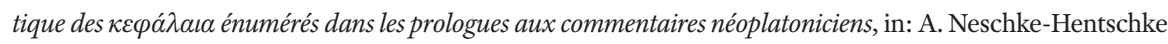
(hrsg.), Argumenta in dialogos Platonis, Teil 1: Platoninterpretation und ihre Hermeneutik von der Antike bis zum Beginn des 19. Jahrhunderts, Basel, pp. 149-181.

MANSFELD, J., 1994, Prolegomena. Questions to be settled before the study of an author, or a text, Leiden-New York-Köln.

MartiJn, M., 2006, The eikôs mythos in Proclus' Commentary on the Timaeus, in: H. Tarrant, D. Baltzly (eds.), Reading Plato in Antiquity, London, pp. 151-167. 
Martijn, M., 2010, Proclus on Nature. Philosophy and Its Methods in Proclus' Commentary on Plato’s Timaeus, Leiden-Boston.

Motтa, A. (cur.), 2014, Anonimo. Prolegomeni alla filosofia di Platone, Roma.

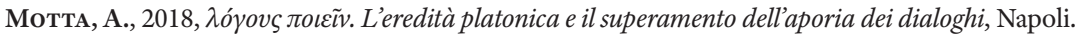

Motte, A., 2000, Discours théologique et prière d'invocation. Proclus héritier et interprète de Platon, in: A.-Ph. Segonds, C. Steel (eds), Proclus et la Théologie platonicienne, Leuven-Paris, pp. 91-108.

Neschke-Hentschke, A., 2000, Der platonische Timaios als Manifest der platonischen Demiurgie, in: A. Neschke-Hentschke (ed./hrsg.), Le Timée de Platon. Contributions à l'histoire de sa réception / Platos Timaios. Beiträge zu seiner Rezeptionsgeschichte, Louvain-la-neue-Louvain-Paris, pp. IX-XXVII.

PlezIA, M., 1949, De commentariis Isagogicis, Kraków.

Radke-Uhlmann, G., 2006, Das Lächeln des Parmenides. Proklos' Interpretationen zur Platonischen Dialogform, Berlin.

REYDAMS-Schils, G. J. (ed.), 2003, Plato’s Timaeus as Cultural Icon, Notre Dame IN.

RuniA, D. T., 1997, The Literary and Philosophical Status of Timaeus' Prooemium, in: T. Calvo, L. Brisson (eds.), Interpreting the Timaeus / Critias, Sankt Augustin.

Runia, D. T., Share, M. (eds.), 2008, Commentary on Plato's Timaeus, vol. II, Book 2: Proclus on the Causes of the Cosmos and its Creation, Cambridge.

STEel, C., 2003, Why should we prefer Plato's Timaeus to Aristotle's Physics? Proclus' Critique of Aristotle's Causal Explanation of the Physical World, in: R. W. Sharples, A. Sheppard (eds.), Ancient Approaches to Plato's Timaeus, London, pp. 175-187.

Tarrant, H. (ed.), 2007, Proclus. Commentary on Plato's Timaeus, vol. I, Book 1: Proclus on the Socratic State and Atlantis, Cambridge.

Trouillard, J., 1982, La mystagogie de Proclos, Paris.

Tzamalikos, P., 2016, Anaxagoras, Origen, and Neoplatonism. The Legacy of Anaxagoras to Classical and Late Antiquity, Berlin-Boston.

Westerink, L. G. (ed.), 1962, Anonymous Prolegomena to Platonic Philosophy, Amsterdam.

Westerink, L. G., Trouillard, J., A.-Ph. Segonds, 1990, Anonyme. Prolégomènes à la philosophie de Platon, Paris 1990.

\section{A NNA MOTTA \\ / Free University of Berlin, Germany / anna.motta@fu-berlin.de}

\section{Putting Cosmogony into Words: The Neoplatonists on Metaphysics and Discourse $(\log o s)$}

The present paper focuses on some aspects of the Neoplatonist literarymetaphysical theory, which has clearly been expressed in the anonymous Prolegomena to Plato's philosophy and further confirmed in Proclus' exegesis of the Timaeus. Thus, this contribution, examines and compares several passages from the Prolegomena and from Proclus' Commentary on the Timaeus with a view to showing that it is legitimate to speak of a certain cosmogony of the Platonic dialogue that is analogous to that of the macrocosm. Moreover, the analogy between macrocosm and microcosm makes it possible to further investigate the 
similarity between the $\lambda$ ó $\gamma$ os- $\zeta \tilde{\omega}$ ov of the Demiurge and that of Timaeus, on the one hand, and the reality which the $\lambda$ óyos expresses, on the other. This similarity turns out to be both structural/morphological and content-related/semantic. Thus, by combining the natural and theological science, the analysis of the "generation" of the macrocosm and microcosm brings out the strongly analogical nature of Plato's dialogues, which is particularly visible in the Timaeus.

KEY WOR DS

Plato, Demiurge, macrocosm, microcosm, analogy, metaphysics, literary theory 